\title{
PERSEPSI ALUMNI TERHADAP MATA KULIAH ANTI KORUPSI PADA KURIKULUM AKUNTANSI 2014 (STUDI KASUS ALUMNI PRODI AKUNTANSI UNIVERSITAS RIAU KEPULAUAN BATAM)
}

\author{
Firdaus Hamta \\ Dosen Tetap Prodi Akuntansi Universitas Riau Kepulauan Batam
}

\begin{abstract}
Abstrak
Indonesia salah satu negara dengan jumlah kasus korupsi yang tinggi dan meluas dari pusat pemerintahan sampai ke daerah-daerah. Fenomena yang membangun citra buruk akibat maraknya praktek korupsi di Indonesia menjadi informasi yang di konsumsi publik sehari-hari, maka fakta tersebut menanamkan pesimisme dikalangan akademik dan masyarakat sebagai bangsa yang menjunjung tinggi hukum.

Diterimanya secara terbuka bahkan dirasakan sangat menyenangkan dalam belajar mata kuliah anti korupsi, merupakan persepsi positif bagi para alumni prodi akuntansi Unrika Batam, karena alumni prodi akuntansi merasakan mendapat ilmu baru yang bermuara pada hati nurani dan etika, jiwa amanah serta tanggungjawab, dan merasakan belajar menghargai hak orang lain dan lain-lain. Ha lain, karena materi yang memiliki relevansi dalam pengolahan keuangan atau akuntansi khususnya menciptakan akuntabilitas dan menjunjung tinggi profesionalitas sebagai akuntan atau tanaga accounting di lapangan kerja.

Disamping itu, ilmu anti korupsi juga dianggap penting sebagai upaya pencegahan, membentengi diri bahkan dapat membangun nilai-nilai sosial untuk aktif dimasyarakat seperti mensosialisasikan gerakan anti korupsi khususnya bagi para alumni prodi akuntansi Unrika Batam, karena fenomena korupsi dianggap masalah bersama dan ada disekitar atau didaerah bahkan menjadi tayangan umum di media cetak dan televisi maupun media sosial.
\end{abstract}

\section{Kata Kunci : Persepsi Alumni dan Mata Kuliah Anti Korupsi}

\section{Pendahulauan}

Korupsi merupakan suatu tindakan yang sangat tidak terpuji, di mana di Indonesia salah satu negara dengan jumlah kasus korupsi yang tinggi dan meluas dari pusat pemerintahan sampai ke daerah-daerah. Citra buruk akibat maraknya praktek korupsi di Indonesia menjadi informasi yang di konsumsi publik sehari-hari, fakta tersebut menanamkan pesimisme kalangan masyarakat dan dunia akademik sebagai bangsa yang menjunjung tinggi hukum.

Indonesia Corruption Watch (ICW) dalam Suradi (2014:63) bahwa, korupsi diartikan sebagai bentuk penyimpangan ketidakjujuran berupa pemberian sogokan, upeti, terjadinya pertentangan kepentingan kelalaian dan pemborosan yang memerlukan rencana dan strategi 
yang akan memberikan keuntungan kepada pelakunya. Sedangkan bentuk-bentuk korupsi menurut David Wijaya (2014:11) dikelompokkan atas tiga yakni, (1) pengkhianatan kepercayaan, (2) penyalahgunaan kepercayaan, (3) penyalahgunaan kekuasaan agat bisa memperoleh keuntungan materi.

Persoalan korupsi juga sesungguhnya bukan hanya persoalan hukum tapi sebelumnya adalah persoalan sistem dan akuntabilitas dari penyelenggara negara. Maka jiwa akuntabel yang mengatur tatanan dan pertanggungjawaban keuangan sangat melekat dalam akuntansi. Artinya bahwa peran akuntabilitas keuangan perlu ditantanamkan sejak dini termasuk pada mahasiswa di Indonesia.

Program Studi Akuntansi Unrika Batam, memasukkan mata kuliah anti korupsi dalam kurikulum tahun 2014, disamping itu penekaan basis keperilakuan dalam diri mahasiswa juga menjadi perhatian dalam membentuk karakter generasi akuntabel, beretika dan anti korupsi. Maka beberapa kurikulum di Prodi Akuntansi Unrika Batam diharapkan saling mendukung satu sama lain seperti antara mata kuliah anti korupsi dengan keprilakuan akuntansi.

Beberapa yang mendasar dalam mata kuliah tersebut adalah pengertian korupsi, faktor penyebab korupsi, dampak masif korupsi, nilai dan prinsip anti korupsi, upaya pemberantasan korupsi, instrumen Internasional pencegahan korupsi, tindak pidana korupsi dalam peraturan perundang-undangan, dan peran Mahasiswa dalam gerakan antikorupsi.

Maka peran kurikulum dalam mencetak tata nilai (karakter) bangsa Indonesia khususnya generasi muda (mahasiswa) sangat penting, dan persiapan sejak dini dengan mentalitas anti korupsi merupakan upaya pencegahan yang sangat baik bagi masa depan Indonesia.

Berdasarkan uraian diatas, maka penulis tertarik untuk melakukan penelitian yang berjudul "Persepsi Alumni Terhadap Mata Kuliah Anti Korupsi pada Kurikulum 


\section{Akuntansi 2014 (Studi Kasus Alumni Prodi Akuntansi Universitas Riau Kepulauan Batam).}

\subsection{Batasan Masalah}

Penulis menyadari keterbatasan baik dari aspek pengetahuan maupun waktu, maka penulis membatasi masalah penelitian ini yakni, hanya pada konteks persepsi alumni atas penerapan mata kuliah anti korupsi pada kurikulum tahun 2014 di Prodi Akuntansi Unrika Batam.

\subsection{Rumusan Masalah}

Berdasarkan uraian di atas, maka rumusan permasalahan pada penelitian ini adalah, bagaimana persepsi alumni terhadap penerapan anti korupsi pada kurikulum Prodi Akuntansi Unrika Batam?

\subsection{Tujuan Penelitian}

Adapaun tujuan penelitian ini bertujuan adalah, untuk mengetahui persepsi alumni terhadap penerapan Anti korupsi pada kurikulum tahun 2014 di Prodi Akuntansi Unrika Batam.

\subsection{Manfaat Penelitian}

Dalam penelitian ini, adapun yang menjadi manfaat dalam penelitian ini, diharapkan sebagai berikut:

a. Bagi penulis

Untuk mengetahui konidisi riil dilapangan khusus tentang tema penelitian, menambah wawasan dan pengetahuan penulis.

b. Bagi institusi terkait 
Diharapkan menjadi bahan masukan bagi universitas khususnya tentang pentingnya memahami persepsi alumni pada mata kuliah anti korupsi.

c. Bagi peneliti selanjutnya

Sebagai bahan tambahan referensi atau literatur untuk melakukan pengembangan penelitian selanjutnya.

\subsection{Kerangka Berpikir}

II. Metodologi Penelitian

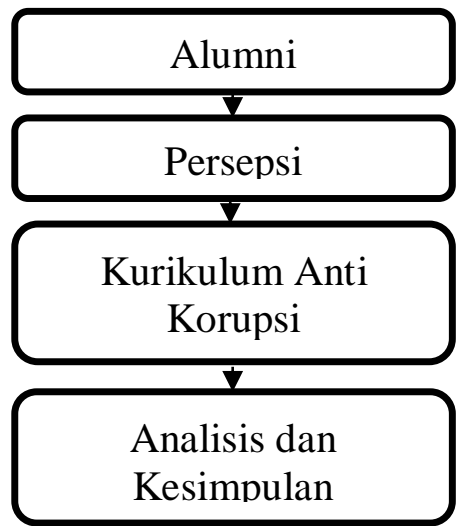

\subsection{Objek Penelitian}

Objek penelitian ini dilaksanakan di jalan Batu Aji Baru No. 99 Batam, pada alumni prodi akuntansi tahun 2014 dan 2015 Unrika Batam.

\subsection{Waktu Penelitian}

Jadwal dan aktivitas penelitian dilakukan seperti pada tabel berikut ini:

Tabel 2.1 Waktu Penelitian

\begin{tabular}{|c|l|c|c|c|c|c|c|c|c|}
\hline \multirow{3}{*}{ No } & \multirow{3}{*}{ Kegiatan } & \multicolumn{4}{c|}{ Desember } & \multicolumn{5}{c|}{ Januari } \\
\cline { 3 - 9 } & & \multicolumn{3}{|c|}{2015} & \multicolumn{4}{c|}{2016} \\
\hline & & I & II & III & IV & I & II & III & IV \\
\hline 1 & Observasi Awal & & & & & & & & \\
\hline 2 & Pengumpulan Data & & & & & & & & \\
\hline 3 & Laporan & & & & & & & & \\
\hline
\end{tabular}




\subsection{Populasi dan Sampel}

Penelitian pada kualitatif menurut Mukhtar (2013) bahwa, karaktertik populasi dan sampel terdiri atas dua yaitu homogen dan heterogen. Karakteristik homogen adalah karakter yang dimiliki oleh suatu populasi relatif sejenis, artinya walaupun jumlah populasi besar tetapi dia memiliki karakter yang sejenis, sampel yang ditetapkan tidak perlu besar cukup 5\% saja sudah dianggap mewakili populasi tersebut. Bahkan dalam penelitian kualitatif tidak mesti didasarkan pada prosesntase, tetapi dapat dilakukan dengan menetapkannya sesuai kebutuhan, baik secara snowball atau purposive sampling. Sedangkan populasi heterogen, yakni populasi dan sample yang relatif beragam atau bervariasi, baik jenis pekerjaan, tingkat pendidikanm etnis, atau suku hingga agama, ini mengharuskan seorang penelitian memperbesar jumlah sampelnya, hal ini dimaksudkan sampel yang ditetapkan benar-benar dapat mewakili populasi yang ada. Maka dianjurkan lebih besar prosesntase mininal 5 hingga 10\%. Populasi pada penelitian ini yakni alumni prodi akuntansi Unrika Batam pada Tahun 2014 dan 2015, dan untuk mendapatkan hasil yang repsentatif dari informan (sampel) maka ditetapkan sebanyak 50 alumni dari lebih kurang 255 alumni. Namun akan berkembang jika masih ditemukan informasi (data) baru sampai kepada data jenuh.

\subsection{Metode Penelitian}

Adapun metode penelitian yang penulis gunakan dalam menyusun penelitian ini dengan menggunakan metode penelitian kualitatif diskriptif. Menurut Sugiyono (2010), adalah penelitian yang digunakan untuk meneliti pada kondisi objek alamiah dimana peneliti merupakan instrumen kunci. 


\subsection{Teknik Pengumpulan Data}

Teknik pengumpulan data dalam penelitian ini terdiri dari beberapa hal, adalah sebagai berikut:

\section{Observasi}

Melakukan peninjauan lapangan (lokasi) penelitian, baik observasi awal maupun dalam pengumpulan data.

2. Metode Kepustakaan

Mengumpulan kebutuhan teori yang berhubungan dengan penelitian yang dilakukan baik dengan membaca buku, jurnal, dan lain-lain.

3. Wawancara

Melakukan tanya jawab secara langsung terhadap sampel (informan) dan unsur-unsur yang berkompoten terhadap masalah yang diangkat dalam penelitian.

4. Alat Bantu Handphone Celluller (HP)

Alat komunikasi yang membantu dilaksanakannya wawancara (komunikasi) baik berupa Short Massage Service (SMS), Black Berry Massenger (BBM) dan Whats Up (WA).

\subsection{Definisi Operasional}

Persepsi sebagai gambaran seseorang tentang sesuatu objek yang menjadi fokus permasalahan yang sedang terjadi. Adapun faktor-faktor yang mempengaruhi persepsi adalah sebagai berikut (1) faktor Individu, Individu dalam membuat suatu persepsi akan dilatarbelakangi oleh kemampuan individu untuk mempelajari sesuatu (attitude), motivasi individu untuk membuat persepsi tentang sesuatu tersebut, kepentingan individu terhadap sesuatu yang dipersepsikan, pengalaman individu dalam menyusun persepsi, serta harapan individu dalam menentukan persepsi tersebut. (2) faktor situasi, situasi dalam menyusun suatu persepsi ditentukan momen yang tepat. (3) faktor target, gangguan yang ada dalam menyusun 
persepsi sebagai gangguan dalam menentukan target atau persepsi, biasanya adalah objek yang akan dipersepsikan merupakan perihal yang benar-benar baru (novelty), adanya gambaran hidup yang mempengaruhi dalam membentuk persepsi (motion), suara - suara yang timbul pada saat membentuk persepsi (sounds), ukuran dari bentuk persepsi (size), yang melatarbelakangi pembentuk persepsi tersebut (background), dan kedekatan persepsi dengan objek lain yang dapat membentuk persepsi yang hampir sama (proximity), serta kesamaan (similarity) dari persepsi yang akan dibangun dengan persepsi lain. Manahan (2008:63-64).

\subsection{Teknik Analisis Data}

Teknik analisis data dilakukan dengan pengumpulan data sampai kepada kecukupan data sekaligus sebagai wujud pengujian kualitas data (uji keabsahan data), dan dilakukan dengan melakukan triangulasi data dengan teori yang sebelumnya dilakukan reduksi data dalam penyajian data, serta melakukan analisa dan menarik kesimpulan. Berikut ini klasifikasi dalm teknik analisis data:

\section{1). Kecukupan Data}

Menurut Chaedar Alwasilah (2014), kutipan diatas dijelaskan sebagai berikut bahwa pengumpulan data kualitatif lazimnya berhenti manakala dirasakan adanya satu atau lebih dari empat hal berikut:

a) Exchaution of sources, yakni ketika sumber-sumber data sudah terkuras habis sehingga tidak ada data yang tersisa.

b) Saturations of categories, yakni segala kategori sudah habis terpakai untuk mewadahi data sehingga tidak ada data yang tersisa.

c) Emergence of regularities, atau tatkala ditemukan keteraturan atau pola-pola yang dapat diprediksi. 
d) Overextension, atau tatkala informasi yang ditemukan jauh dari kategori-kategori yang sudah ada.

\section{2). Penyajian Data}

Mattheww dan Michael dalam Hamid Patilima (2004), dibagi tiga alur kegiatan yang terjadi secara bersamaan, ringkasnya adalah sebagai berikut:

a) Reduksi Data

Sebagai proses pemilihan, pemusatan perhatian pada penyederhanaan, pengabstrakan, dan transformasi data yang muncul dari catatan-catatan lapangan. Reduksi data merupakan bagian dari analisis yang menajaminkan, menggolongkan, mengarahkan, membuang yang tidak perlu, dan mengorganisasi data dengan sedemikian rupa hingga kesimpulan-kesimpulan akhirnya dapat ditarik dan di dan diverifikasi.

b) Penyajian Data

Sekumpulan informasi tersusun, yang memberi kemungkinan adanya penarikan kesimpulan dan tindakan. Penyajian data yang sering digunakan pada kualitatif pada masa lalu adalah bentuk teks naratif, dan menyederhanakan informasi yang kompleks kedalam bentuk kesatuan bentuk yang disederhanakan dan selektif atau konfigurasi yang mudah dipahami.

c) Penarikan Kesimpulan

Dari permulaan pemgumpulan data, peneliti mulau mencari arti benda-benda, polapola, penjelasan, konfigurasi-konfigurasi yang mungkin, alur sebab-akibat, dan proposisi. Penarikan kesimpulan, hanyalah sebagian dari suatu kegiatan dari konfigurasi yang utuh. Pembuktian kembali atau verifikasi dapat dilakukan untuk mencari pembenaran dan persetujuan, sehingga validitas dapat tercapai.

\section{3). Analisis Deskriptif Kualitatif}


Desain penelitiannya secara total dan lebih banyak mengkonstruksi format penelitian dan strategi memperoleh data di lapangan tapi tetap longgar dan terbuka terhadap teori. Atau starategi yang lebih banyak menganalisis permukaan data dan hanya memperhatikan prosesproses kejadian suatu fenomena, bukan pendalaman data atau makna data. (Burhan Bungin, 2011).

III. Pembahasan

\section{A. Hasil Wawancara}

Berikut ini adalah beberapa kutipan persepsi dari hasil wawancara penulis dengan informan (sampel), adalah sebagai berikut:

Sangat Senang, karena mengetahui tindakan korupsi dan Hukum yang pantas serta Menambah wawasan.

Menghilangkan sikap korupsi dari diri sebagai Upaya pencegahan dan Pemahaman luas tentang korupsi di Indoenesia.

Bangga, dan akan membudayakan Anti Korupsi dan sebagai usaha untuk mempersiapkan dan memperbaiki diri agar jauh dari korupsi dan dapat menanamkan kesadaran tinggi untuk anti korupsi di Indonesia.

Setuju, mengetahui lebih luas hokum di Indonesia dan dan bentuk korupsi serta menjadi pribadi anti korupsi karena paham dengan seluk beluknya sehingga dapat menambah ilmu dan membentengi diri dari korupsi, sehingga menjadi teladan anti korupsi.

Sangat senang karena menjadi pedoman hidup dan menjadi acuan anti korupsi juga mengetahui resikonya.

Setuju sekali, karena kita dapat menghargai hak orang dan pribadi dan peka pada korupsi baik di sekolah. Sehingga menjadi manusia yang amanah.

Saya sangat antusias, karena menjadi tau contoh korupsi, menghidari korupsi, memiliki integritas dan menjadi pribadi yang anti korupsi untuk rakyat Indonesia, karena tanpa korupsi rakyat sejahtera.

Menyenangkan, dapat ilmu baru dan memahami sehingga bisa sosialisasi anti korupsi dan anti korupsi sehingga terhindari dari korupsi. 


\section{B. Triangulasi Data}

Tabel 31. Hasil Triangulasi Data

\begin{tabular}{|c|c|c|}
\hline Indikator & Teori & Data \\
\hline \multirow[t]{3}{*}{$\begin{array}{l}\text { Faktor } \\
\text { Individu }\end{array}$} & $\begin{array}{l}\text { 1. Kemauan dan } \\
\text { kemampuan (sikap) }\end{array}$ & $\begin{array}{ll}\text { 1. } & \text { Senang } \\
\text { 2. } & \text { Ilmu baru } \\
\text { 3. } & \text { Penting } \\
\text { 4. } & \text { Setuju } \\
\text { 5. } & \text { Bagus } \\
\text { 6. } & \text { Apresiasi } \\
\text { 7. } & \text { Menerima } \\
\text { 8. Sangat setuju } \\
\text { 9. Antusias } \\
\text { 10. Sangat Baik } \\
\text { 11. Menyenangkan } \\
\text { 12. Sangat Antusias } \\
\text { 13. Sangat penting } \\
\text { 14. Semangat } \\
\text { 15. Sangat senang }\end{array}$ \\
\hline & 2. Motivasi & $\begin{array}{l}\text { 1. Mengetahui tindakan korupsi } \\
\text { 2. Menghilangkan sikap korupsi } \\
\text { dari diri } \\
\text { 3. Memperbaiki diri } \\
\text { 4. Mengetahui hukum } \\
\text { 5. Membentengi diri } \\
\text { 6. Acuan dan Pedoman hidup } \\
\text { 7. Menghargai hak orang dan } \\
\text { 8. Untuk menjadi jujur } \\
\text { 9. Menjadi anti korupsi } \\
\text { 10. Fenomenal } \\
\text { 11. Ikut aja } \\
\text { 12. Penasaran } \\
\text { 13. Bermanfaat. }\end{array}$ \\
\hline & 3. Harapan & $\begin{array}{l}\text { 1. Berperan Aktif dalam Anti } \\
\text { Korupsi } \\
\text { 2. Mencegah Korupsi } \\
\text { 3. Tegak nya Hukum } \\
\text { 4. Upaya pencegahan } \\
\text { 5. Membudayakan Anti Korupsi } \\
\text { 6. Memiliki Kesadaran tinggi } \\
\text { 7. Upaya mencegah } \\
\text { 8. Menjadi pribadi anti korupsi } \\
\text { 9. Menjadi teladan anti korupsi }\end{array}$ \\
\hline
\end{tabular}




\begin{tabular}{|c|c|c|}
\hline & & $\begin{array}{l}\text { 10. Zero korupsi } \\
\text { 11. Peka pada korupsi } \\
\text { 12. Bisa sosialisasi anti korupsi } \\
\text { 13. Menambah wawasan baru } \\
\text { 14. Mendapata Ilmu hati nurani } \\
\text { 15. Ada Gerakan anti korupsi } \\
\text { 16. Aplikasi atau bertindak } \\
\text { 17. Memiliki Rasa Tanggung } \\
\text { jawab. }\end{array}$ \\
\hline \multirow[t]{2}{*}{ Faktor Situasi } & $\begin{array}{lll}\text { 1. } & \text { Situasi dan } \\
\text { kebutuhan } & \end{array}$ & 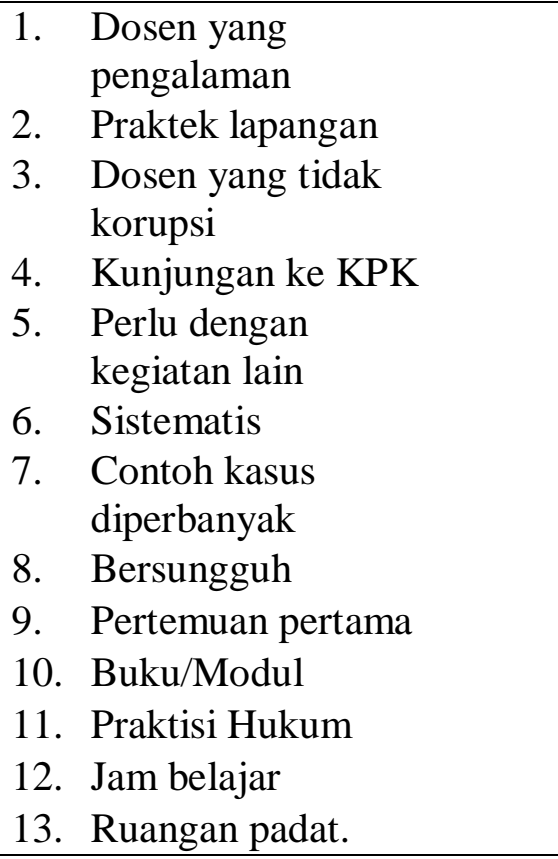 \\
\hline & \begin{tabular}{|ll} 
2. & $\begin{array}{l}\text { Kehidupan } \\
\text { (nyata) }\end{array}$
\end{tabular} & $\begin{array}{ll}\text { 1. } & \text { Fenomenal } \\
\text { 2. } & \text { Ada disekitar kita } \\
\text { 3. } & \text { Konsumsi media } \\
\text { 4. } & \text { Tontonanan. } \\
\end{array}$ \\
\hline Faktor Target & 1. Kendala & $\begin{array}{ll}\text { 1. } & \text { Interaksi sangat } \\
\text { kurang } \\
\text { 2. } & \text { Satu kelas jangan } \\
\text { penuh } \\
\text { 3. } \\
\text { 4. }\end{array}$ \\
\hline
\end{tabular}




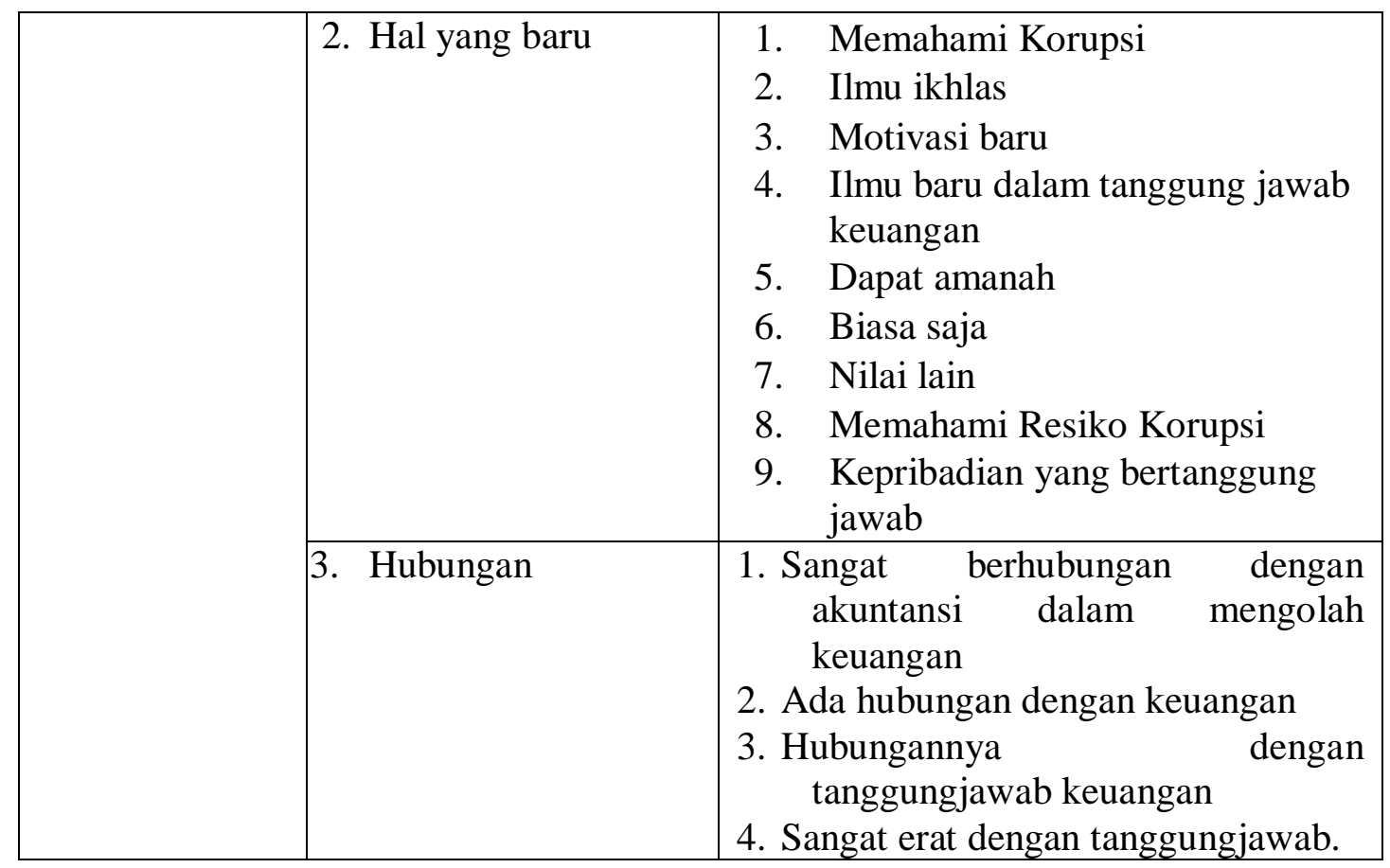

\section{Frekwensi}

\begin{tabular}{|l|c|c|}
\hline \multicolumn{1}{|c|}{ Alternatif Jawaban } & Frekuensi & Persentase \\
\hline Sangat Setuju Sekali & 42 & $85 \%$ \\
\hline Setuju Sekali & 7 & $14 \%$ \\
\hline Setuju & 0 & $0 \%$ \\
\hline Kurang Setuju & 1 & $1 \%$ \\
\hline Tidak Setuju & 0 & $0 \%$ \\
\hline Total & 50 & $100 \%$ \\
\hline
\end{tabular}

Sumber : Data Primer

\section{Analisis}

1) Faktor Individu

Umumnya alumni prodi akuntansi menerima secara terbuka dengan penerapaan mata kuliah anti korupsi di kurikulum prodi akuntansi tahun 2014 Unrika Batam. Beberapa faktor pribadi yang mendorong alumni menerima dengan baik mata kuliah anti korupsi karena merasakan beberapa hal seperti menjadi ilmu baru yang memberikan pemahaman bentuk dan jenis korupsi, hukum korupsi, yang pada akhirnya menjadi dasar membangun benteng diri terhadap tindakan korupsi. 
Adanya faktor individu tersebut terindetifikasi adanya dorongan dari alumni untuk terlibat dalam gerakan sosialisasi kem masyarakat untuk penceagahan korups, dan minat untuk aktif dan menyelenggarakan kegiatan-kegiatan kemasyarakatan dalam pembinaan upaya pencegahan anti korupsi. Karena umumnya alumni merasakan bahwa ilmu anti korupsi adalah ilmu hati nurani, yang dapat mendorongnya bersikap amanah dan menghargai hakhak orang lain serta memiliki rasa tanggung jawab bersama terhadap persoalan korupsi di Indonesia.

\section{2) Faktor Situasi}

Secara umum pelaksanaan proses belajar mengajar mata kuliah anti korupsi relatif baik dalam persepsi alumni prodi akuntansi unrika. Namun beberapa hal yang perlu mendapat perhatian adalah perlu adanya kegiatan-kegiatan lain seperti kunjungan akademik ke lembaga yang menangani korupsi atau hukum, serta peran aktif aparatur penegak hukum dalam memberikan sosialisasi di kampus.

Metode belajar mengajar umumnya alumni membutuhkan modul dan bedah kasus dan sarana prasaran yang memadai, sedangkan dari aspek sosial pentingnya mata kuliah anti korupsi karena dianggap korupsi adalah masalah bersama serta ada disekitar atau didaerah, bahkan menjadi konsumsi publik akibat tayangan umum di media cetak dan televisi maupun media sosisal.

\section{Faktor Target}

Interaksi dan waktu belajar yang lebih luas menjadi perhatian bagi alumni dalam belajar mengajar mata kuliah anti korupsi. Hal ini sangat penting karena menyangkut keprilakuan, etika, hati nurani yang memiliki hubungan kuat dengan profesi akuntan atau praktisi akuntansi. Dampak dari faktor target akan mendorong untuk munculnya sifat-sifat amanah, jujur dan rasa tanggung jawab yang tinggi bagi alumni akuntasi Unrika Batam tahun 2014 dan 2015. Sehingga para alumni merasakan nilai-nilai amanah, kejujuran dan rasa tanggung 
jawab dapat mendorongnya membentuk keprilakuan dalam mengaplikasikan keuangan (akuntansi) di lapangan kerja dan sangat mendukung profesionalitas.

\section{Kesimpulan dan Saran}

\subsection{Kesimpulan}

Diterimanya secara terbuka bahkan dirasakan sangat menyenangkan dalam belajar mata kuliah anti korupsi, merupakan persepsi positif bagi para alumni prodi akuntansi Unrika Batam. Karena alumni prodi akuntansi merasakan mendapat ilmu baru yang bermuara pada hati nurani dan etika, jiwa amanah serta tanggungjawab. Hal ini dianggap penting dalam pengolahan keuangan atau akuntansi.

Ilmu anti korupsi dianggap penting sebagai upaya pencegahan, membentengi diri bahkan nilai sosial untuk aktif mensosialisasikan gerakan anti korupsi bagi para alumni prodi akuntansi Unrika Batam. Karena fenomena korupsi dianggap masalah bersama dan ada disekitar atau didaerah bahkan menjadi tayangan umum di media cetak dan televisi maupun media sosial.

Dengan adanya mata kuliah anti korupsi tersebut alumni merasakan mendapat dukungan moril dan pembekalan moril untuk menjunjung tinggi profesionalitas profesi sebagai seorang calon akuntan, atau menjaga prilaku yang akuntabel dalam pengolahan keuangan di lapangan kerja.

\subsection{Saran}

1. Perlu adanya kegiatan-kegiatan lain seperti kunjungan akademik ke lembaga yang menangani korupsi atau hukum, serta peran aktif aparatur penegak hukum dalam memberikan sosialisasi di kampus. 
2. Metode belajar mengajar membutuhkan modul dan bedah kasus dan sarana prasarana yang memadai.

3. Interaksi dan waktu belajar yang lebih luas, hal ini sangat penting karena menyangkut keprilakuan, etika, hati nurani yang memiliki hubungan kuat dengan profesi akuntan atau praktisi akuntansi.

\section{DAFTAR PUSTAKA}

Ahmad, dkk. 1998. Pengembangan Kurikulum. Bandung, CV Pustaka Setia.

Arindita. 2003. Hubungan antara Persepsi Kualitas Pelayanan dan Citra Bank dengan Loyalitas Nasabah.Skripsi (tidak diterbitkan). Surakarta, Fakultas Psikologi UMS.

Burhan Bungin, 2011. Penelitian Kualitatif, edisi 2, Surabaya. Kencana.

Chaedar Alwasilah, 2014. Pokoknya Studi Kasus Pendekatan Kualitatif, Bandung, Kiblat Buku Utama.

Chaplin,J. P. 2008. Kamus Psikologi Lengkap. Jakarta, PT Raja Grafindo.

Davidoff, Linda L. 1981. Psikologi Suatu Pengantar. (Introduction to Phsychology, Second ed). Alih bahasa, Mari Juniati (ed). Surabaya. Erlangga. Gelora Aksara Pratama.

David Wijaya, 2014. Pendidikan Anti Korupsi. Jakart, Indeks.

Filedman. Robert S. 1999. Understanding Psychology. Singapore: McGrow Hill College.

Gitosudarmo \& Sudita. 2000. Perilaku Keorganisasian, Edisi Pertama. Jogjakarta. Erlangga.

Hamid Patilima, 2004. Metode Penelitian Kualitatif. Jakarta. Alfabeta.

Manahan. 2008. Environmental Chemistry. 5th Ed. Lewis Publisher. Michigan. Universitas.

Morgan. 1987. Images of Organization, SAGE Publications, Inc, Newbury Park, Californi.

Muchlas, Makmuri. 2008. Perilaku Organisasi. Yogyakarta. Gadjah Mada University Press.

Mukhtar, 2013. Metode Praktis Penelitian Deskriptif Kualitatif. Jakarta, Referensi.

Mulyana, Deddy. 2005. Ilmu Komunikasi Suatu Pengantar. Bandung. PT. RemajaRosdakarya.Pusat Bahasa Departemen Pendidikan Nasional.1990. Kamus Besar BahasaIndonesia.Jakarta : Balai PustakaSalim, Agus. 2006. Teori dan Paradigma Penelitian Sosial. Buku Sumber UntukPenelitian Kualitatif. Edisi kedua. Yogyakarta. Tiara Wacana.

Nasution. 1988. Asas-asas Kurikulum. Bandung. Jemmars, Bandung.

Rakhmat, Jalaluddin. 1996. Psikologi Komunikasi. Edisi kesepuluh. Bandung, Rosdakarya.

Sarwono. Sarlito. 2009. Pengantar Psikologi Umum. Jakarta, Rajawali Press.

Saylor, J. Galen and Alexander, William M. 1974. Planning Curriculum for Scholls. New York, Hote Rine hart and Winston, Inc. 
Shaleh, Abdul Rahman \& Wahab, Muhbib Abdul. 2004. Psikologi Suatu Pengantar Dalam Persfektif Islam. Jakarta, Kencana.

Sobur, Alex. 2003. Psikologi Umum. Bandung, Pustaka Setia.

Staden, Chris. 2000. The Value Added Statement: Bastion of Social Reporting or Dinosaur of Financial Reporting? Massey University, New Zealand.

Stenberg, J Robert. 2008. Psikologi Kognitif. Yogyakarta, Pustaka Pelajar.

Sugiyono. 2010. Metode Penelitian Kuantitatif Kualitatif dan R\&D. Bandung, Alfabeta.

Suradi. 2014. Pendidikan Anti Korupsi. Yogyakarta, Gava Media.

Thoha, Miftah, 2000. Perilaku Organisasi - Konsep Dasar dan Aplikasinya, PT. Raja Grafindo Persada, Jakarta.

Walgito, Bimo. 2004. Pengantar Psikologi Umum. Yogyakarta. Andi OffsetWidayatun, T.R. 1999. Ilmu Prilaku M.A. Jakarta. Fajar Interpratama.

Winardi. 1992. Manajemen Perilaku Organisasi. Bandung, Citra Aditya Bakti. 